УДК 631.33.022.1

\title{
ОБОСНОВАНИЕ ТИПА ЦЕНТРАЛИЗОВАННОЙ СИСТЕМЫ ВЫСЕВА И ЕЕ ЭЛЕМЕНТОВ ДЛЯ ШИРОКОЗАХВАТНОЙ ЗЕРНОВОЙ СЕЯЛКИ
}

\author{
Н. Д. Лепёшкин ${ }^{1}$, В. В. Мижурин ${ }^{2}$, С. В. Савчук ${ }^{3}$
}

\author{
${ }^{1}$ Ведущий научный сотрудник лаборатории обработки почвы и посева \\ РУП «НПЦ НАН Беларуси по механизации сельского хозяйства», Минск, Республика Беларусь, канд. техн. наук, доцент \\ 2 Научный сотрудник лаборатории обработки почвы и посева \\ РУП «НПЦ НАН Беларуси по механизации сельского хозяйства», Минск, Республика Беларусь \\ ${ }^{3}$ Доцент кафредры «Машиностроение и эксплуатация автомобилей» учреждения образования \\ Брестский государственный технический университет, канд. техн. наук, доцент
}

\begin{abstract}
Реферат
В статье приведен анализ высевающих систем, распределительных и дозирующих устройств посевных машин, на основании которого сделано обоснование выбора типа высевающей системы, распределительного и дозирующего устройства, применительного к широкозахватным посевным машинам.
\end{abstract}

Ключевые слова: система высевающая, машина посевная широкозахватная, устройство распределительное, устройство дозирующее.

\section{JUSTIFICATION OF THE TYPE OF CENTRALIZED SEEDING SYSTEM AND ITS ELEMENTS FOR A WIDE-REACH GRAIN SEEDER}

\section{Abstract}

\section{N. D. Lepeshkin, V. V. Mizhurin, S. V. Sauchuk}

The article provides an analysis of seeding systems, distribution and metering devices of seeding machines, on the basis of which a justification of the choice of the type of seeding system, distribution and metering device, in relation to wide-grip seeding machines is made.

Keywords: Seeding system, wide-reach seeding machine, distribution device, dosing device.

\section{Введение}

Одной из важнейших технологических операций в технологиях возделывания сельскохозяйственных культур является посев, от качества и своевременности выполнения которого в значительной степени зависит судьба урожая.

Анализ отечественного и зарубежного опыта показывает, что одним из основных направлений повышения качества и производительности посева является применение широкозахватных сеялок и почвообрабатывающе-посевных агрегатов, в конструкциях которых применен принцип централизованного дозирования с пневматическим транспортированием семян к сошникам. При использовании в таких агрегатах одного централизованного бункера большой емкости существенно сокращается время на заправку и обслуживание, а следовательно, создаются предпосылки к повышению производительности труда на посеве.

В настоящее время на ряде предприятий республики освоено производство сеялок и посевных агрегатов шириной захвата до 9 метров и ёмкостью бункера до 6000 л. В тоже время широко известными зарубежными фирмами-производителями посевных машин (Lemken, Horch, Amazone и др.) налажен выпуск сеялок шириной захвата 12 и более метров и ёмкостью бункера 8000 л и более. Практика использования этих сеялок, например сеялки Citan 12000 фирмы «Amazone», в Республике Беларусь показала их высокую производительность и высокое качество при посеве зерновых культур. С учетом этого для более существенного повышения производительности на посеве возникла необходимость разработки отечественной сеялки шириной захвата 12 метров. Поскольку пневматические высевающие системы, применяемые на зарубежных сеялках имеют различные схемы, в которых для выполнения технологического процесса могут использоваться различные распределительные и дозирующие устройства, то вопрос обоснования их выбора для перспективной отечественной сеялки является актуальным.

\section{Основная часть}

Пневматические высевающие системы состоят из централизованного бункера с дозирующим устройством, пневмотранспортирующей сети с вентилятором, распределительного устройства, механизмов привода вентилятора и дозаторов. При этом привод вентилятора на широкозахватных сеялках, как правило, осуществляется от гидромотора.

В мировой практике наибольшее распространение получили высевающие системы, содержащие централизованный бункер из которого дозирование семян осуществляется несколькими дозирующими устройствами, число которых может достигать 16 штук (системы высева с групповым дозированием) и системы высева, где дозирование осуществляется одним или двумя дозирующими устройствами (системы высева с централизованным дозированием).

К преимуществам последней относится то, что они более универсальны для высева различного посевного материала, т. к. дозирование происходит при большой производительности. Принцип работы этих систем заключается в следующем: дозирующие устройства производят подачу семян с заданной нормой высева в поток воздуха, создаваемого вентилятором, с помощью которого они перемещаются по пневмотранспортирующей сети к распределительному устройству. В распределительном устройстве семена равномерно распределяются по выходящим из распределительного устройства патрубкам и далее поступают в сошники. При этом известные технологические схемы высевающих систем в основном отличаются устройством для ввода семян в воздушный поток.

В настоящее время ввод семян в воздушный поток осуществляется за счет создания эжекции в зоне ввода семян или за счет выравнивания давления в бункере и пневмотранспортной сети. В первом случае используются эжекторные устройства, которые состоят из конфузора и диффузора, расположенных на расстоянии друг от друга, образуя тем самым зону, в которой создается эффект разряжения, что и обеспечивает беспрепятственный ввод семян. В этом случае бункер изготавливается негерметичным (открытым) и системы называются открытыми или без надува (рисунок 1). 


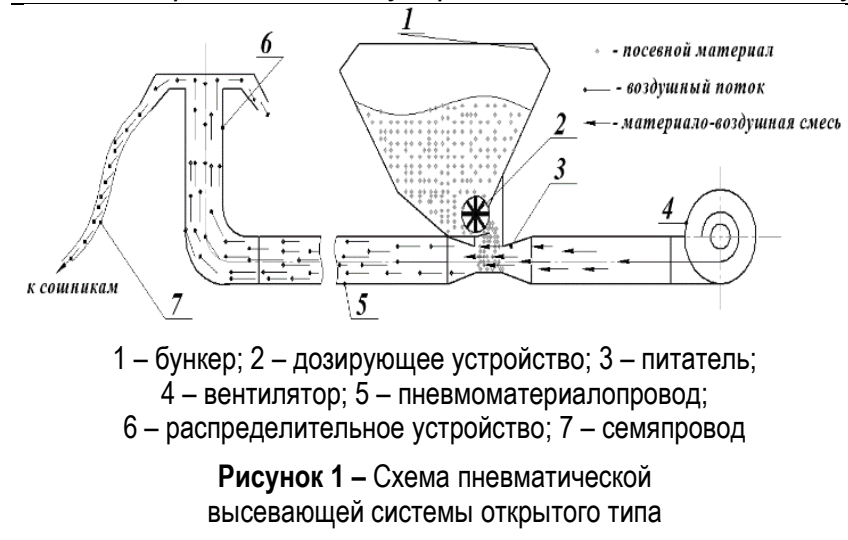

Во втором случае бункер изготавливается герметичным, а воздушный поток воздуха, создаваемый вентилятором, направляется не только в пневмотранспортную сеть, но и в бункер. Здесь за счет герметизации давление в бункере и пневмотранспортной сети выравниваются, и поток семян от дозирующего устройства также беспрепятственно поступает в пневмотранспортную сеть (рисунок 2).

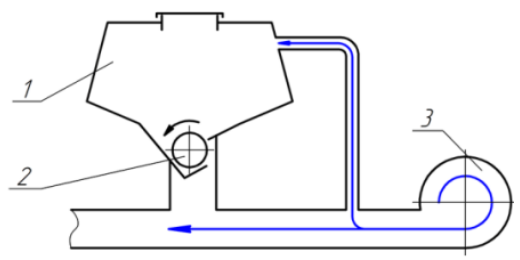

a)

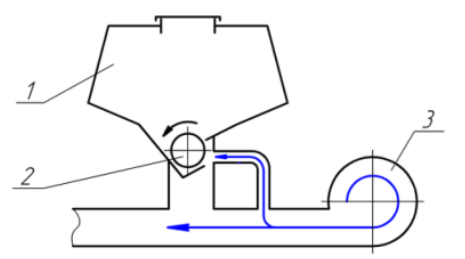

б)

а) с подачей непосредственно в бункер;

б) с подачей в бункер через дозирующее устройство

1 - бункер; 2 - дозирующее устройство; 3 - вентилятор

Рисунок 2 - Схема пневматической

высевающей системы закрытого типа

В этой схеме различают два способа подачи воздуха в бункер: непосредственно от вентилятора (рисунок 2, а) или через дозирующее устройство (рисунок 2, б). Считается, что второй способ обеспечивает большую стабильность, Т. к. быстрее реагирует на изменение давления в пневмосети, а поэтому более приемлем. Такая система называется закрытой (с надувом).

Анализ этих схем систем показывает, что, несмотря на свою надежность, меньшие требования к эксплуатации, открытая система высева не пригодна для широкозахватных сеялок шириной более 9 метров, т. к. в этих случаях давления, создаваемого вентилятором, может быть недостаточно для транспортирования посевного материала к сошникам. Поэтому закрытые системы, хотя и более сложны и требуют качественного изготовления её узлов для недопущения потерь воздуха, но обеспечивают транспортирование семян при меньшем расходе воздуха и давлении. Причем энергозатраты на подачу семян у сеялок закрытыми системами высева, как показывают исследования [1] на 18-20\% ниже, чем у сеялок с открытыми системами. Наряду с уменьшением расхода воздуха уменьшается и расход масла для гидропривода вентилятора, что в определенных условиях, позволяет исключить необходимость установки специальной гидростанции.

Распределительное устройство посевного материала является одной из наиболее важных частей пневматической системы высева посевных машин. Они должны обеспечивать равномерное распределение посевного материала, поступающего от питающих (дозирующих) устройств по сошникам. В мировой практике известны $[2,3]$ два типа распределительных устройств - горизонтальный и вертикальный. Однако первый тип распределительных устройств из-за ряда своих особенностей широкого распределения, применительно к широкозахватным посевным машинам не получил. Наибольшее распространение здесь получили распределяющие устройства вертикального типа, и, в первую очередь, устройства пассивного действия. Вместе с тем, как показывают испытания и практика использования посевных машин с распределяющими устройствами вертикального типа в хозяйствах республики $[4,5]$, они не в полной мере обеспечивают агротехнические требования по неравномерности распределения посевного материала по сошникам.

Основной причиной, которая обуславливает неравномерное распределение посевного материала по сошникам наряду с неправильным подбором технологических режимов, является несовершенство их конструкции.

Особенностью конструкции распределительного устройства вертикального типа применительно к широкозахватным посевным машинам является то, что если для машин, ширина которых не превышает шести метров, распределительное устройство в основном совмещают с питателем, то для машин шириной более шести метров распределительные устройства располагают на некотором удалении от питателя (до 4-6 м), что предполагает наличие дополнительного прямолинейного участка на входе в распределитель. Поэтому распределительное устройство вертикального типа, не совмещенное с питателем, как правило, представляет собой вертикальную колонну к нижнему сочленению которой присоединен отвод (коленообразный патрубок), а к верхнему - распределительная головка, с установленными на боковой поверхности отводящими патрубками, соединенными семяпроводами с сошниками. Принцип работы такого устройства заключается в следующем. Воздушный поток, создаваемый вентилятором, транспортирует посевной материал от питателя к распределительному устройству, при входе в которое происходит изменение направления движения с горизонтали на вертикаль (движение в отводе), далее посевной материал поступает в вертикальную колонну, где создается восходящий поток материало-воздушной смеси, который затем направляется в распределительную головку и далее, отражаясь от крышки распределительной головки, направляется через отводящие патрубки в сошники.

В процессе движения посевного материала по вертикальному распределительному устройству можно выделить три основных участка: 1 - участок ввода посевного материала в распределительное устройство (отвод), 2 - участок разгона и распределения посевного материала в поперечном сечении (вертикальная колонна); 3 - участок распределения посевного материала по семяпроводам (распределительная головка) (рисунок 3).

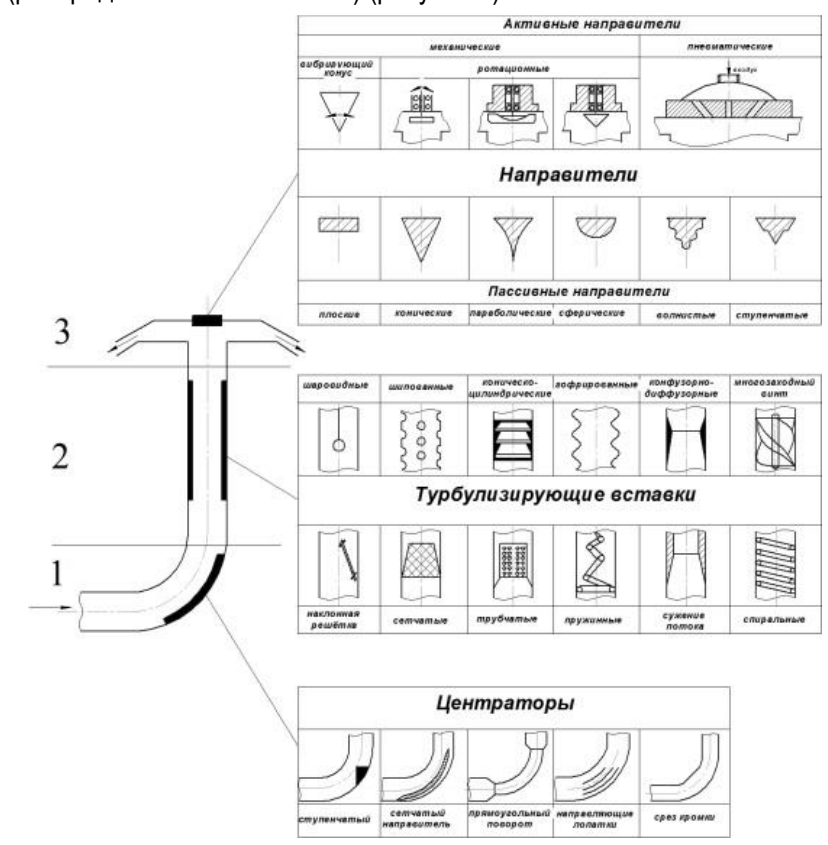

1 - отвод; 2 - вертикальная колонна; 3 - распределительная головка

Рисунок 3 - Схема вертикального распределительного устройства и дополнительных элементов 
Вестник Брестского государственного технического университета. 2021

С целью совершенствования процесса распределения посевного материала в распределительном устройстве на его участках размещают дополнительные элементы различного конструктивного исполнения, способствующие созданию более однородной материало-воздушной смеси по сечению этих участков.

Так, в отводе для выравнивания потока смеси и подачи его в центр вертикальной колонны устанавливают центраторы, которые могут быть различного вида: ступенчатые, сетчатые, в виде прямоугольного поворота, направляющих лопаток, среза кромки и др. В вертикальной колонне для выравнивания концентрированного потока посевного материала по ее поперечному сечению применяют турбулизирующие вставки, которые способствуют увеличению турбулентности потока и, соответственно, выравниванию. По конструкции вставки могут быть шаровидными, шиповидными, коническоцилиндрическими, гофрированными, конфузорно-дифффузорными, сетчатыми, трубчатыми, пружинными, спиральными, в форме наклонной решетки, сужения потока и др. В распределительной головке устанавливаются направители, которые, снижая травмирование посевного материала (косое соударение), направляют его равномерно по отводящим патрубкам. Эти устройства также имеют различную геометрическую форму: плоскую, коническую, параболическую, сфрерическую, волнистую и ступенчатую. Особо следует отметить распределительные головки с активными направителями, которые по воздействию на посевной материал могут быть механическими, где в качестве основного рабочего органа выступают вибрирующие или ротационные элементы (лопасти, конусы), а так же пневматическими, в которых на посевной материал воздействует воздушный поток.

Таким образом, можно сделать вывод о том, что для улучшения работы вертикальных распределительных устройств целесообразно использовать дополнительные элементы. При этом надо отметить, что применение дополнительного элемента только на одном участке распределительного устройства бывает недостаточно. Поэтому в большинстве случаев заводы-изготовители применяют дополнительные элементы на нескольких участках. В основном этими участками являются вертикальная колонна и распределительная головка.

Кроме распределительного устройства, одним из основных рабочих органов посевной машины, влияющих на качество посева, является дозирующее устройство. Поэтому при выборе дозирующего устройства необходимо помнить, что оно должно отвечать следующим агротехническим требованиям [6]:

- неустойчивость общего высева не должна превышать 3 \% для зерновых, 5 \% - для зернобобовых и $10 \%$ - для минеральных удобрений и трав;

- дробление семян зерновых культур должно быть не более 0,5 \%, зернобобовых - не более $1 \%$;

- отклонение фактической нормы высева от заданной не должно превышать $\pm 5 \%$ - для семян зерновых и зернобобовых культур, $\pm 10 \%$ - для семян трав и $\pm 10 \%$ - для удобрений.

Кроме этого дозирующее устройство должно подавать посевной материал равномерно без пульсаций, т. е. обеспечивать одинаковое расстояние между семенами вдоль рядка независимо от заполнения бункера, рельефа поля, наклона посевной машины и изменения скорости ее движения, а также быть универсальным и легким в настройке.

Для удовлетворения указанных требований по мере развития конструкций посевных машин были предложены и предлагаются до настоящего времени различные типы дозирующих устройств.

Однако, несмотря на их многообразие, так и не создано дозирующее устройство, полностью отвечающее предъявляемым к нему требованиям.

Для анализа и оценки с выявлением достоинств и недостатков конструкции известных дозирующих устройств нами предложена уточненная классификация (рисунок 4), которая опирается на принцип действия дозирующих устройств, особенности выполняемого ими технологического процесса и используемые для этих целей рабочие органы. При разработке классификации были изучены и проанализированы литературные источники $[7,8]$, патенты
Республики Беларусь, России, Украины, Германии, США, Японии, проспекты различных фирм и др. материалы, отражающие конструкцию дозирующих устройств посевных машин.

Из рисунка 4 видно, что известные к настоящему времени конструкции дозирующих устройств по принципу действия можно разделить на три типа: пневматические, пневмомеханические и механические.

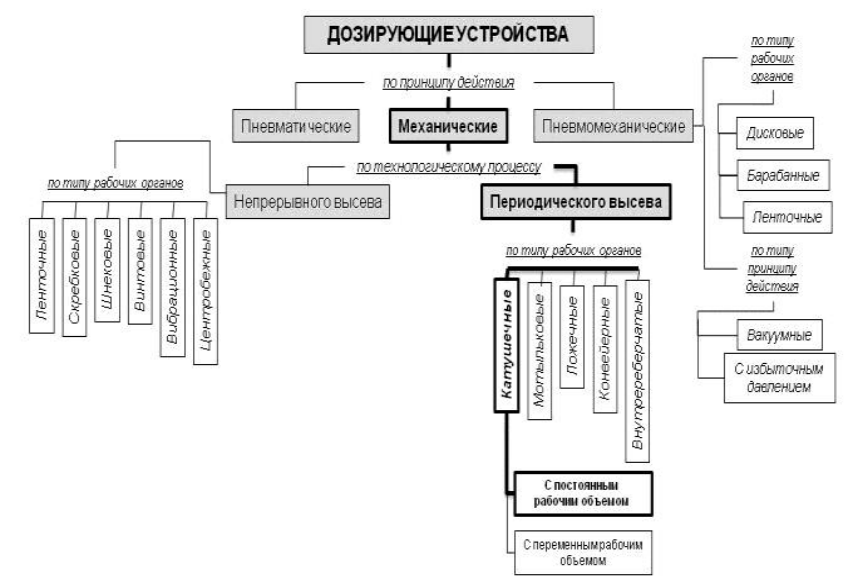

Рисунок 4 - Классификация дозирующих устройств посевных машин

Пневматические устройства в чистом виде не получили широкого распространения на посевных машинах из-за сложности конструкции. Наиболее распространены пневматические дисковые дозирующие устройства. Такие устройства устанавливаются в основном на сеялках точного высева. Например, устройства, работающие на принципе вакуума, установлены на сеялках СУПН-8, СУПН-6 (Украина), СПБ-8К, СПБ-12К, СТВ-107, СПКА-8 (Россия), СТВ-8К, $8 К У, ~ 12,12 У$ (Беларусь), а также сеялках фирм «Noted», «Ebra», «Rilolea», «Riviere-Casalis» (Франция), «Gaspardo» (Италия), «Becker», «Hassia» (Германия) и др., а устройства, работающие на принципе нагнетания воздуха в семенную камеру - на сеялках фирм «Karl Becker», «International Hurvester», «Cyclo», «AllisChalmers» (США), «Riviere-Casalis» (Франция) и др.

Что касается посева зерновых культур, то известно всего лишь несколько пневматических и пневмомеханических устройств, предназначенных для этих целей $[9,10]$, которые так и не были применены на серийных машинах из-за ряда недостатков, основными из которых являются необходимость подержания постоянных параметров воздушного потока, сложность установки нормы высева. Поэтому по принципу действия наибольшее распространение получили механические дозирующие устройства [11] и, в первую очередь, механические устройства периодического действия. Дозирующие устройства непрерывного действия (вибрационные, центробежные, шнековые, ленточные, скребковые), т. е. те устройства, у которых рабочий орган обеспечивает непрерывную подачу посевного материала, из-за ряда существенных недостатков применяются лишь на отдельных посевных машинах. Так, вибрационные дозирующие устройства не могут дозировать посевной материал с различными физико-механическими свойствами и обладают низкой универсальностью, центробежные - имеют высокую зависимость нормы высева от устойчивости движения посевной машины, шнековые обладают высокой энергоемкостью и т. д.

Механические дозирующие устройства периодического действия, как и непрерывного действия также весьма многообразны по конструкции. К ним относятся мотыльковые, ложечные, конвейерные, внутриреберчатые, катушечные и другие. Анализ конструкций этих устройств показывает, что, например, мотыльковый дозатор по своей конструкции является самым простым. Здесь рабочим органом выступает мотылек, который обычно имеет 6-8 крыльев, которые располагаются радиально в плоскостях, проходящих через ось вращения, либо под углом около 350 к плоскости вращения [12]. Семена 
высеваются через отверстия в дне или стенке бункера под действием вращающегося под отверстием мотылька 2 (рисунок 5).

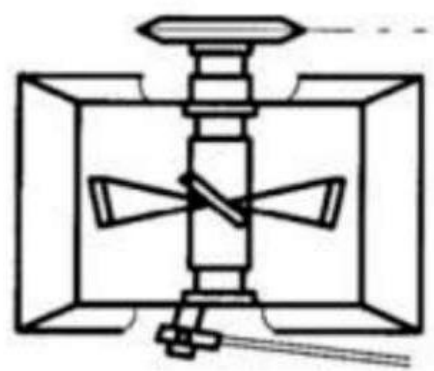

Рисунок 5 - Мотыльковое дозирующее устройство

Норму высева регулируют заслонками, изменяя выходное сечение окон. Однако, несмотря на простоту конструкции, данный аппарат в настоящее время практически не используется, т. к. обладает рядом недостатков: количество высеваемого материала зависит от высоты насыпи семян в бункере, уклона местности и толчков.

Ложечные и конвейерные высевающие аппараты (рисунок 6) работают по принципу вычерпывания $[13,14,15,16,17]$.

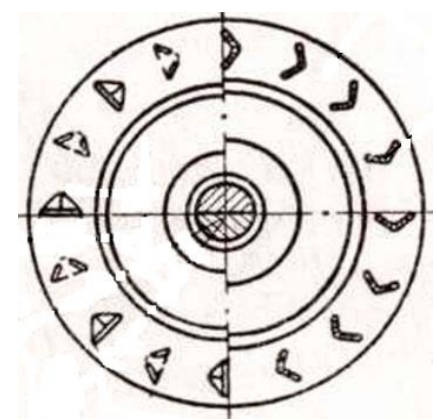

a)

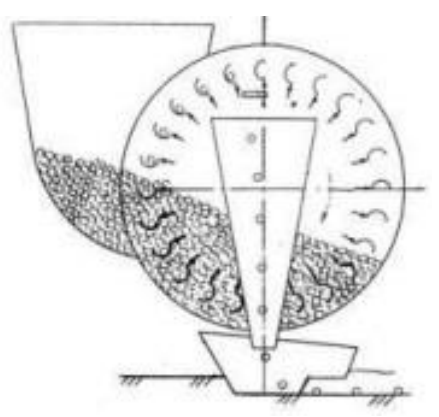

б)

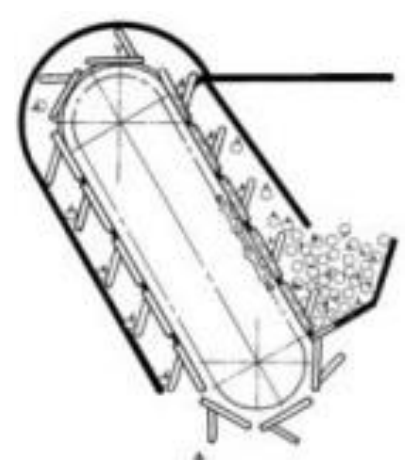

B)

a, 6 - ложечный высевающего аппарат; в - конвейерный аппарат

Рисунок 6 - Дозирующие устройства
Здесь ложечки могут устанавливаться как индивидуально, так и группами. Геометрические параметры ложечек подбираются в соответствии с физико-механическими характеристиками высеваемого материала. Поэтому механизатору приходится иметь ряд комплектов ложечек и менять их при каждом переходе с культуры на культуру. Кроме того эти аппараты очень чувствительны к толчкам и наклонам, неудобны в обслуживании и сложны в настройке на заданные нормы высева.

Внутриреберчатое дозирующее устройство применяется для высева зерновых и некоторых крупносемянных культур (рисунок 7).

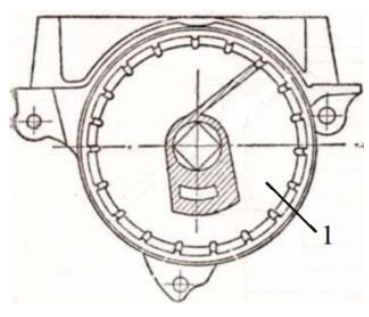

a)

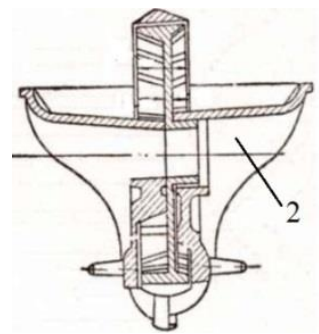

б) а - вид сбоку; б - вид спереди

1 - диск; 2 - корпус дозатора

Рисунок 7 - Внутриреберчатое дозирующее устройство

В данном устройстве высев регулируется частотой вращения диска 1 , а в отдельных конструкциях шириной канала. Несмотря на то, что в данном устройстве влияние активного движения слоя семян сведено к минимуму, но из-за недостаточной универсальности оно также не получило широкого распространения.

В настоящее время наибольшее распространение в современных посевных машинах получили дозирующие устройства катушечного типа, которые в наибольшей мере удовлетворяют агротехническим требованиям при посеве семян различных культур $[18,19,20]$.

Дозирующие устройства такого типа для обеспечения высева различных по размерам семян могут изготавливаться с переменным или постоянным рабочим объемом. Классическим примером дозирующих устройств с переменным рабочим объемом, обеспечивающих требуемые нормы высева как мелкосемянных (травы), так и среднесемянных (зерновые) культур, являются устройства, включающие реберчатую катушку, муфту, подпружинный клапан и розетку с прорезями (сеялки семейства С3-3,6). Здесь изменение рабочего объема осуществлялось с помощью изменения длины рабочей части катушки и изменения зазора между катушкой и клапаном. В то же время для этих целей фирмы «Lemken», «Amazone», «Rabe» (Германия), «Vederstadt» (Швеция) на большинстве своих посевных машинах используют комбинированные катушки, состоящие из катушек для высева мелко- и среднесемянных культур, а фирма «Kverneland» (Германия), «Gaspardo» (Италия) - катушку с изменяемой глубиной желобков. Последняя используется на отечественных сеялках СПУ.

Однако, несмотря на свои преимущества и широкое распространение на посевных машинах, при работе дозирующих устройств с переменным рабочим объемом наблюдается пульсация потока высеваемых семян и неустойчивость нормы высева. Это объясняется для большинства дозирующих устройств наличием активного слоя. Поскольку толщина активного слоя непостоянная, ввиду ее зависимости от сил внутреннего трения между семенами, окружной скорости ребер желобков, вида семян, то и высев семян катушкой пульсирующе-порционный, а не равномерный. Кроме того уменьшение длины рабочей части катушек также негативно сказывается на качестве высева. Для устранения указанных недостатков в последние годы ряд ведущих фирм по производству посевных машин используют для дозирования семян устройства, в которых отсутствует активный слой, а катушки изготовлены сменными и имеют постоянный рабочий объем. При этом катушки могут быть выполнены желобчатыми, штифтовыми или ячеистыми (рисунок 8). 
Вестник Брестского государственного технического университета. 2021

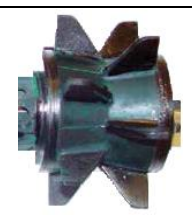

a)

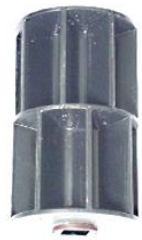

г)

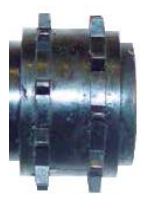

б)

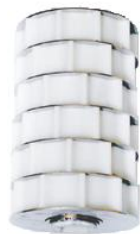

Д)

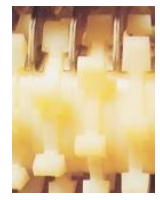

B)

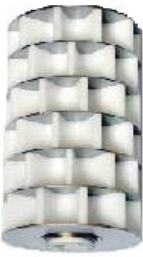

e)

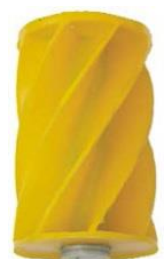

ж) а, б, в - штифтовые катушки фирмы: «Lemken», «Amazone»; г, д, е, ж-желобчатые катушки фирмы «Amazone»

Рисунок 8 - Конструкции катушек дозирующего устройства

Для снижения пульсаций, например при использовании желобчатой катушки, она может быть изготовлена из нескольких частей, смещенных относительно друг друга (фирма «Lemken», «Amazone») или изготовлена с наклоном желобков к их оси вращения (фирма «Morris», «Amazone»).

Таким образом, согласно классификации (рисунок 4) дозирующее устройство для перспективных посевных машин по принципу действия должно быть механическим, по технологическому процессу - периодического высева, а типу рабочего органа - катушечным с постоянным рабочим объемом. При этом катушка должна быть желобчатой и состоять из нескольких частей, смещенных друг относительно друга, а ребра желобков должны быть установлены под углом к оси вращения катушки. Поскольку активный слой в перспективном дози рующем устройстве должен отсутствовать, то при разработке его конструкции необходимо предусмотреть уплотнитель-формирователь посевного материала в желобках катушки.

\section{Заключение}

1. Перспективная широкозахватная сеялка должна содержать герметичный централизованный бункер с двумя дозирующими устройствами, а система высева должна быть закрытого типа, и ввод семян, поступающих от дозирующих устройств в пневмотранспортную сеть, осуществляться за счет выравнивания давления в бункере и пневмотранспортной сети путем подачи части воздуха от вентилятора в бункер через дозирующее устройство.

2. В перспективной широкозахватной сеялке целесообразно использовать распределительное устройство вертикального типа, а для снижения неравномерности распределения семян по сошникам в его конструкции применять дополнительные элементы. В вертикальной колонне - турбулизирующую вставку, а в распределительной головке - направитель. Такое конструктивное исполнение позволит обеспечить путем последовательного взаимодействия потока семян с указанными элементами требуемое по агротехнике значение показателя неравномерности распределения семян по сошникам.

3. На основании анализа достоинств и недостатков дозирующих устройств, проведенного с учетом предложенной классификации, установлено, что система высева перспективной широкозахватной сеялки должна комплектоваться механическим дозирующим устройством, которое осуществляет периодический высев без активного слоя, а в качестве рабочего органа должна использоваться катушка с постоянным рабочим объемом и наклоненными к её оси желобками.

\section{Список цитированных источников}

1. Внуков, И. Е. Направление совершенствования высевающих систем зерновых пневматических сеялок / И. Е. Внуков, Н. И. Любушко // Тракторы и сельскохозяйственные машины. - 1988. - № 1. - С. 23-27.
2. Чеботарев, В. П. Классификация пневматических высевающих систем // В. П. Чеботарев, Н. Д. Лепешкин, Ю. Л. Салапура, Д. В. Зубенко / Научно-технический прогресс в сельскохозяйственном производстве: материалы Междунар. науч.-практ. конф., Минск, 10-11 октября 2012 г.: в 3 т. / РУП «НПЦ НАН Беларуси по механизации сельского хозяйства». - Т.2. - С. 223-228.

3. Распределитель высеваемых материалов пневматических сеялок: пат. 3729 ВҮ, МПК 7 А01С7/00 / Н. Д. Лепешкин, А. А. Точицкий, А. Л. Медведев, Ю. Л. Салапура; заявитель РУП «НПЦ НАН Беларуси по механизации сельского хозяйства». - № 20070030; заявл. 18.01.07; опубл. 18.04.07.

4. Астахов, В. С. Совершенствование пневматических высевающих систем сеялок / В. С. Астахов - Горки : УО «Могилевский гос. учебный центр подготовки повышения квалификации, переподготовки кадров, консультирования и аграр. ресрормы», 2007. $148 \mathrm{c}$.

5. Протокол № 119 Б 1/3 - 2018 Ц от 12.12.2018 года приёмочных испытаний агрегата почвообрабатывающее-посевного АПП - 9 / ГУ «Белорусская МИС» - 2018. - 120 с.

6. Машины посевные и посадочные. Правила установления показателей назначения: ТКП 078-2007. - Введ. 06.08.2007 - Минск : Белорус. научн. ин-т внедрения новых форм хозяйствования в АПК, 2007. - 40 c.

7. Абакумов, А. В. Классификация высевающих аппаратов сеялок и выбор объекта исследования / А. В. Абакумов // Инновационные идеи молодых исследователей для агропромышленного комплекса России: сборник статей Международной научно-практической конференции молодых ученых. Том III / Пензенская ГСХА - Пенза: РИО ПГСХА, 2016. - С. 108-111.

8. Савельев, Ю. А. Анализ и классификация устройств для повышения качества дозирования семян трав высевающими аппаратами / Ю. А. Савельев, А. Н. Крючин // Агропромышленный комплекс: состояние, проблемы, перспективы: сборник статей X Международной научно-практической конференции / МНИЦ ПГСХА. - Пенза : РИО ПГСХА, 2014. - С. 86-89.

9. Бузенков, Г. М. Машины для посева сельскохозяйственных культур / Г. М. Бузенков, С. А. Ма. - М.: Машиностроение, 1976 $272 \mathrm{c}$.

10. Перевозников, В. Н. Повышение эффективности сева хлебных злаков пневматическим высевающим аппаратом: дис. ...к. т. н: 05.20.01 / В. Н. Перевозников - Минск, 1996. - 193 с.

11. Красовских, В. С. Высевающие устройства посевных машин / В. С. Красовских, А. И. Клишин // Вестник АГАУ - 2007. - № 8.

12. Сельскохозяйственная энциклопедия. Т.1 (А-Е) / Ред. коллегия: П. П. Лобанов (гл. ред.) [и др.]. Изд. 3-е, перераб. - М.: Государственное издательство сельскохозяйственной литературы, 1949. $620 \mathrm{c}$.

13. А.С. 1007576 СССР, МКИЗ А01С7/16. Высевающий аппарат / Козичев Н. В., Жигульский А. С., Поляков А. Г., Семенов Л. А., Хегай П. А. и др. - № 3319933/30-15; заяв. 13.07.1981; опубл. 30.03.1983, Бюл. № 12.

14. А.С. 1463159 СССР, МКИЗ А01С7/16. Высевающий аппарат / Соколов В. А., Моргунов Ю. А., Теперенко А. Г., Шинкевич Е. Б., Мумыга Ю. Н., Храмов В. Н. - № 3959170/30-15; заяв. 01.10.1985; опубл. 07.03.1989, Бюл. № 9.

15. Пат. 2095959 РФ: МПК А01C7/04, А01C7/00. Высевающий аппарат / Шиповский Н. А.; Шиповский А. А. - № 96101225/13; заяв. 16.01.1996; опубл. 20.11.1997.

16. Пат. 2305394 РФ: МПК А01С7/16. Высевающий аппарат для проращенных семян / Шапров М. Н., Цепляев А. Н., Бороменский В. П., Абезин В. Г., Карпунин В. В., Абезин Д. А. № 2006102808/12; заяв. 31.01.2006; опубл. 10.09.2007, Бюл. № 25.

17. Пат. 2373678 РФ: МПК А01С7/16. Дисково-ложечный высевающий аппарат для посева проросших семян пропашных культур / Цепляев А.Н., Харлашин А.В., Абезин В.Г. - № 2008125543/12; заяв. 23.06.2008; опубл. 27.11.2009.

18. Пронин, В. М. Надежные и эффективные машины для ресурсосберегающих технологий Поволжья / В. М. Пронин // Техника и оборудование для села. - 2002. - № 9. - С. 8-10. 
Вестник Брестского государственного технического университета. 2021

19. Полторынкин, С. С. Пневмовинтовой высевающий аппарат для трудносыпучих семян / С. С. Полторынкин, А. Н. Цепляев // Сельский механизатор. - 2014. - № 9 (67). - С. 10-11.

20. Серебрянный, М. И. Механизация возделывания зерновых в Канаде / М. И. Серебрянный // Механизация и электрификация. - 1987. №1. - C. 61.

\section{References}

1. Vnukov, I. E. Napravlenie sovershenstvovaniya vysevayushchih sistem zernovyh pnevmaticheskih seyalok / I. E. Vnukov, N. I. Lyubushko // Traktory i sel'skohozyajstvennye mashiny. - 1988. - № 1. - S. 23-27.

2. CHebotarev, V. P. Klassifikaciya pnevmaticheskih vysevayushchih sistem // V. P. CHebotarev, N. D. Lepeshkin, YU. L. Salapura, D. V. Zubenko / Nauchno-tekhnicheskij progress v sel'skohozyajstvennom proizvodstve: materialy Mezhdunar. nauch.-prakt. konf., Minsk, 10-11 oktyabrya 2012 g.: V 3 t. / RUP «NPC NAN Belarusi po mekhanizacii sel'skogo hozyajstva». - T.2. - S. 223-228.

3. Raspredelitel' vysevaemyh materialov pnevmaticheskih seyalok: pat. 3729 BY, MPK 7 A01S7/00 / N. D. Lepeshkin, A. A. To ‘chickij,

A. L. Medvedev, YU. L. Salapura; zayavitel' RUP «NPC NAN Belarusi po mekhanizacii sel'skogo hozyajstva». - № 20070030; zayavl. 18.01.07; opubl. 18.04.07.

4. Astahov, V. S. Sovershenstvovanie pnevmaticheskih vysevayushchih sistem seyalok / V. S. Astahov - Gorki : UO «Mogilevskij gos. uchebnyj centr podgotovki povysheniya kvalifikacii, perepodgotovki kadrov, konsul'tirovaniya i agrar. reformy», 2007. - $148 \mathrm{~s}$.

5. Protokol № 119 B $1 / 3-2018$ C ot 12.12 .2018 goda priyomochnyh ispytanij agregata pochvoobrabatyvayushchee-posevnogo APP - 9 / GU «Belorusskaya MIS»-2018. $-120 \mathrm{~s}$

6. Mashiny posevnye i posadochnye. Pravila ustanovleniya poka-zatele naznacheniya: TKP 078-2007. - Vved. 06.08.2007 - Minsk : Belorus. nauchn. in-t vnedreniya novyh form hozyajstvovaniya v APK, 2007. - $40 \mathrm{~s}$.

7. Abakumov, A. V. Klassifikaciya vysevayushchih apparatov seyalok i vybor ob"ekta issledovaniya / A. V. Abakumov // Innovacionnye idei molodyh issledovatelej dlya agropromyshlennogo kompleksa Rossii: sbornik statej Mezhdunarodnoj nauchno-prakticheskoj konferenci molodyh uchenyh. Tom III / Penzenskaya GSKHA - Penza: RIO PGSKHA, 2016. - S. 108-111.

8. Savel'ev, YU. A. Analiz i klassifikaciya ustrojstv dlya povysheniya kachestva dozirovaniya semyan trav vysevayushchimi apparatami $/$ YU. A. Savel'ev, A. N. Kryuchin // Agropromyshlennyj kompleks: sostoyanie, problemy, perspektivy: sbornik statej X Mezhdunarodnoj nauchno-prakticheskoj konferencii / MNIC PGSKHA. - Penza : RIO PGSKHA, 2014. - S. 86-89.
9. Buzenkov, G. M. Mashiny dlya poseva sel'skohozyajstvennyh kul'tur / G. M. Buzenkov, S. A. Ma. - M.: Mashinostroenie, 1976-272 s.

10. Perevoznikov, V. N. Povyshenie effektivnosti seva hlebnyh zlakov pnevmaticheskim vysevayushchim apparatom: dis. ...k. t .n.: $05.20 .01 /$ V. N. Perevoznikov - Minsk, 1996. - 193 s.

11. Krasovskih, V. S. Vysevayushchie ustrojstva posevnyh mashin / V. S. Krasovskih, A. I. Klishin // Vestnik AGAU - 2007. - № 8.

12. Sel'skohozyajstvennaya enciklopediya. T.1 (A-E) / Red. kollegiya: P. P. Lobanov (gl. red.) [i dr.]. Izd. 3-e, pererab. - M.: Gosudarstvennoe izdatel'stvo sel'skohozyajstvennoj literatury, 1949. - $620 \mathrm{~s}$.

13. A.S. 1007576 SSSR, MKIZ A01C7/16. Vysevayushchij apparat / Kozichev N. V., ZHigul'skij A. S., Polyakov A. G., Semenov L. A., Hegaj P. A. i dr. - № 3319933/30-15; zayav. 13.07.1981; opubl. 30.03.1983, Byul. № 12.

14. A.S. 1463159 SSSR, MKIZ A01C7/16. Vysevayushchij apparat / Sokolov V. A., Morgunov YU. A., Teperenko A. G., SHinkevich E. B., Mumyga YU. N., Hramov V. N. - № 3959170/30-15; zayav. 01.10.1985; opubl. 07.03.1989, Byul. № 9 .

15. Pat. 2095959 RF: MPK A01C7/04, A01C7/00. Vysevayushchij apparat / SHipovskij N. A.; SHipovskij A. A. - № 96101225/13; zayav. 16.01.1996; opubl. 20.11.1997.

16. Pat. 2305394 RF: MPK A01C7/16. Vysevayushchij apparat dlya prorashchennyh semyan / SHaprov M. N., Ceplyaev A. N., Boromenskij V. P., Abezin V. G., Karpunin V. V., Abezin D. A. - № 2006102808/12; zayav. 31.01.2006; opubl. 10.09.2007, Byul. № 25.

17. Pat. 2373678 RF: MPK A01C7/16. Diskovo-lozhechnyj vysevayushchij apparat dlya poseva prorosshih semyan propashnyh kul'tur I Ceplyaev A. N., Harlashin A. V., Abezin V. G. - № 2008125543/12; zayav. 23.06.2008; opubl. 27.11.2009.

18. Pronin, V. M. Nadezhnye i effektivnye mashiny dlya resursosberegayushchih tekhnologij Povolzh'ya / V. M. Pronin // Tekhnika i oborudovanie dlya sela. - 2002. - № 9. - S. 8-10.

19. Poltorynkin, S. S. Pnevmovintovoj vysevayushchij apparat dlya trud nnosypuchih semyan / S. S. Poltorynkin, A. N. Ceplyaev // Sel'skij mekhanizator. - 2014. - № 9 (67). - S. $10-11$.

20. Serebryannyj, M. I. Mekhanizaciya vozdelyvaniya zernovyh v Kanade I M. I. Serebryannyj // Mekhanizaciya i elektrifikaciya. - 1987. - №1. S. 61 .

Материал поступил в редакцию 01.03.2021 